\section{Incidental great public spaces and the role of urban design in South Africa}

\author{
Dario Schoulund \& Karina Landman
}

DOI: http://dx.doi.org/10.18820/2415-0495/trp73.1

Peer reviewed and revised October 2018

*The authors declared no conflict of interest for this title or article

\begin{abstract}
Urban Design in South Africa as a formal profession has a relatively short history. However, in practice, there have been many examples of what must be considered both good and bad Urban Design. There have also been numerous debates at universities and conferences on what Urban Design should be. However, in the constant making and re-making of urban and rural space, Urban Design has a tenuous and weak presence. This article interrogates the rather low profile of Urban Design in the country and why it is not growing or better positioned compared to other countries. This is done through a discussion of three cases that illustrate the often incidental making of great public spaces in contrast to the thoroughly planned approach. The article argues that spontaneous projects of high quality, rather than over-planned projects, where shortcomings result from this preoccupation to rationalise, often have a greater potential to strengthen the role and value of Urban Design. Such an approach would favour incremental, flexible and sensitive proposals and interventions where spontaneity and adaptation are recognised and celebrated, as well as support the notion that urban design should set a framework for many role players to respond to in shaping the city.
\end{abstract}

Keywords: Built environment, incidental public space, South Africa, urban design

\section{TOEVALLIGE GOEIE OPENBARE RUIMTES EN DIE ROL VAN STEDELIKE ONTWERP IN SUID-AFRIKA}

Stedelike Ontwerp in Suid-Afrika as 'n formele beroep het 'n relatiewe kort geskiedenis. In die praktyk was daar egter baie voorbeelde van wat beskou word as beide goeie en slegte stedelike ontwerp. Daar was ook al talle debatte by universiteite en konferensies oor wat stedelike ontwerp moet wees. Nietemin, by die voortdurende vervaardiging en herbou van stedelike en landelike ruimtes is Stedelike Ontwerp egter vaag en swak verteenwoordig. Hierdie artikel ondersoek die redelik lae profiel van stedelike ontwerp in die land en die rede hoekom dit nie groei of beter geposisioneer is in vergelyking met ander lande nie. Dit word gedoen deur ' $n$ bespreking van drie gevallestudies wat die dikwels toevallige maak van goeie openbare ruimtes illustreer in teenstelling met die deeglik beplande benadering. Die artikel argumenteer dat spontane projekte van hoë gehalte, eerder as oorbeplande projekte gebaseer op ' $n$ beheptheid om te rasionaliseer, dikwels 'n groter potensiaal het om die rol en waarde van stedelike ontwerp te versterk. So 'n benadering sal eerder fokus op inkrementele, buigsame en sensitiewe voorstelle en intervensies waar spontaneiteit en aanpassing erken en gevier word, asook die idee dat stedelike ontwerp 'n raamwerk moet vorm vir baie rolspelers om saam te werk om die stad te vorm.

Sleutelwoorde: Bou-omgewing, toevallige openbare ruimte, Suid-Afrika, stedelike ontwerp

\section{DIBAKA TSE KGOLO TSA BATHO BOHLE TSE ENTSWENG KA BOOMO LE MOSEBETSI WA MORALO WA MOTSE SETOROPO AFRIKA BORWA}

Moralo wa motse setoropo Afrika Borwa jwalo ka profeshene e molaong, o na le nalane/histori e kgutshwane. Le ha ho le jwalo, tshebetsong, ho bile le mehlala e mengata ya tseo di shejwang ka hore bobedi, ke moralo o motle hape le o mobe wa toropo. Hape ho bile le dipuisano tse ngata diyunivesithing le dikhonferenseng ka seo moralo wa toropo o tlamehileng ho ba sona. Le ha ho le jwalo, ketso le ketso botjha e sa fetoheng ya sebaka sa toropo le mahae, moralo wa toropo o na le boteng bo sa bonahaleng le bo fokolang. Atikele ena e botsollotsa profaele e tlase ya moralo wa toropo ka hare ho naha le hore ke hobaneng e sa hole kapa e bewe hantle papisong le dinaha tse ding. Sena se etswa ka puisano ya diketsahalo tse tharo tse bontshang ketso ya ka boomo ya ka mehla ya dibaka tse kgolo tsa batho bohle ho fapana le mokgwa/tsela e entsweng ka kelohloko. Atikele ena e phea kgang ya hore diprojeke tsa maemo a hodimo tse etswang ka ho rata, e seng tse rerilweng ho feta tekano e bile ditshito tse hlahang ho tswa ho tlhokeho ena ya ho etsa diphethoho, hangata di na le bokgoni bo bongata ba ho tiisa mosebetsi le boleng ba moralo wa toropo. Katamelo ya mofuta ona e ka thusa ditlhahiso le boqapi bo eketsehileng, bo fetohang ha bobebe le bo thonkgehang ha bobebe, moo teng dintho tse etswang ka ho rata le boitlwaetso di bonwang, le ho ketekwa; hammoho le ho tshehetsa kgopolo ya hore moralo wa motse setoropo, o tlamehile ho etsa moralo wa tshebetso bakeng sa bankakarolo ho arabela popong ya toropo.

\section{INTRODUCTION}

It is somewhat surprising that the Urban Design profession in South Africa is perceived as weak or undefined compared to other countries and to the global growing trend experienced post-1980s (Madanipour, 2006). The contributing factors are complex and many. The small numbers of practitioners, of which currently a mere 76 are registered with the Urban Design Institute of South Africa [UDISA] and the current shortage of education options, as only two tertiary institutions, the University of the Witwatersrand and the University of Cape Town, offer Urban Design in the form of a master's Degree, set a limited professional platform. These aspects do not necessarily speak of stagnation, but rather of slow growth.

Another limiting factor is the blurred line between professions that essentially operate in the same field and the multidisciplinary nature of Urban Design. Architecture is easily associated with the built environment 
and with buildings, in particular, to the same degree Civil Engineering is associated with infrastructure. These are wide professional areas with equally recognisable subfields: Green Architecture, Regionalist Architecture, Structural Engineering, Traffic Engineering, to name a few. For Urban Design, the association to a particular field of recognisable stand is compromised in that it deals with components that primarily belong to other professions such as Landscape Architecture, Architecture, Traffic and Service Engineering, City Planning, and so on. Consequently, the perceived identity of Urban Design leans more towards quality and added-value to components usually related to other fields. Thus, undertakings such as urban re-generation, urban upgrades, re-functionalisation and similar are better associated with Urban Design, more as actions of quality improvement than specific physical components. The many overlapping areas shared with other professionals in the industry contribute to the consensual nature of the task facing the urban designer. This is inherent to its multidisciplinary nature, but represents negotiations, trade-offs and mediation processes that are not conducive to a clear professional definition.

Is the search for definition then a limiting act? In the built environment industry, the more defined professions are not necessarily limited. Architects have, to a large extent, succeeded in having a strong influence on what traditionally, and mostly exclusively, have been engineering projects. Current pioneers such as Sir Norman Foster, Santiago Calatrava or Enrique Browne have decisively opened a wide door to designers to conceptualize, enhance and mediate the ways in which civil infrastructure contributes to the city-making or city-upgrading process. This message has been clearly understood by government officials and developers worldwide. It is not uncommon that, in setting a budget for specific infrastructure projects, the architectural or aesthetic character would be contemplated. Urban Designers, as specialists of the scenario in which these projects are eventually implemented, are at a vantage point to take a strong position in adding value to the process of planning. This could represent the difference between a quality-based conception or a cosmetic embellishment of the different and potentially disjointed parts of significant interventions.

How does this influence the role of urban design in South Africa and does it explain the often weak presence of urban design in practice? Can urban design strengthen its role and identity by making a case for spontaneous, incidental processes leading to great public spaces and assets to cities? This article explores these questions by reflecting on projects that were unintended, where no professionals have been purposely involved, but that have contributed to clearly define the value and role of Urban Design as both a process and a product. By contrast, carefully rationalized, visualized and planned projects call for the precise fitting of all the components, in order to achieve a specific outcome, leaving reduced margins for variations, changes in direction, or adaptation. Lessons learnt from both scenarios, and how they can be incorporated in practice, could prove instrumental for the growth of the profession in South Africa. The three case studies are based on research conducted for a master's thesis, as well as participation in urban design projects. Although the nature of the cases varies widely, the purpose of the article is not to compare the cases, but to reflect on the process and product of these in practice, in order to explore the role of urban design as both a profession and a discipline, and consider the future growth of the profession in the country.

In doing so, the article argues that urban design can play a significant role in the establishment of a framework for other role players to respond to and in the building of, as David Crane articulated it, a city of a thousand designers. Urban design's role should, therefore, be concerned not only with the nature of the profession, but also with the promotion and value of the discipline. Prior to discussing the three cases, the article briefly reviews the role and relevance of urban design internationally and in South Africa.

\section{RECONSIDERING THE ROLE AND RELEVANCE OF URBAN DESIGN}

Madanipour (2006) argues that Urban Design plays an important role and is taken seriously by producers, regulators and users of urban space. The significance for producers relates to the potential of Urban Design to shape the built environment, co-ordinate and lead the development process, and stabilise market conditions. For regulators, including various spheres of governments, the importance of Urban Design lies in the promotion of the city and its ability to shape the future thereof. This also includes efforts to manage environmental change. Finally, Urban Design also has the ability to improve how places function and to enhance their symbolic value, thus influencing the lives of the users of urban spaces.

However, there are various views on the role and relevance of Urban Design internationally. Loew (2011) maintains that, in some countries, for example India, Argentina and Brazil, Urban Design plays a prominent role, while in others such as Spain and Sweden, it tends to be recognised less. However, although Urban Design has flourished in some countries such as the USA, it has often focused on major 'flagship projects', while the real impact on the ground has been less, due to a reluctance to deal with certain challenges such as informality, urban fragmentation, non-place realms, climate change, and unhealthy neighbourhoods (Loukaitou-Sideris, 2012: 475). At the same time, Chapman (2011) maintains that, while there is evidence that Urban Design is establishing itself as a mainstream discipline, most of the 
developed planning systems are struggling to include urban design as part of public policy. He continues to point out that this is due to inconsistencies in statutory plans and non-statutory instruments, differences of disciplinary focus and practices and the fact that changes in the built environment are driven by multiple and disconnected actions.

In order to address some of these challenges, Loukaitou-Sideris (2012: 481) calls for a greater focus on the normative goals of Urban Design and simultaneously expanding its scope and perspective through contextualising and embedding; stitching and repurposing; weaving and interfacing, as well as greening and sustaining.

Emphasising this notion of contextspecific design, Chapman (2011) promotes the idea of engaging with places through localising design and planning. He maintains that it is the role of urban designers to ensure that all the incremental changes progressively improve the quality of place by appreciating the complex ways in which places develop. It, therefore, calls for regenerative design and development where urban designers are prepared to understand change as nonlinear, emerging from complex relationships, accept and work with change, and then adapt to emerging needs in a specific context through enabling co-evolution of human beings and nature (Mang \& Haggard, 2014). This would mean listening to both the people and the place (biophysical environment) in a real way. Hence, "the significance of urban design lies in the role it plays in the overall transformation of cities" (Madanipour, 2006: 191) and the way in which the environment is transformed.

In spite of this significance, the role of Urban Design in South Africa remains tenuous and weak. Initial indications point towards the following contributing factors. There is the notion that Urban Design is only for 'luxury projects' and upmarket areas. With a few exceptions such as on the Cape Flats, there has generally been a

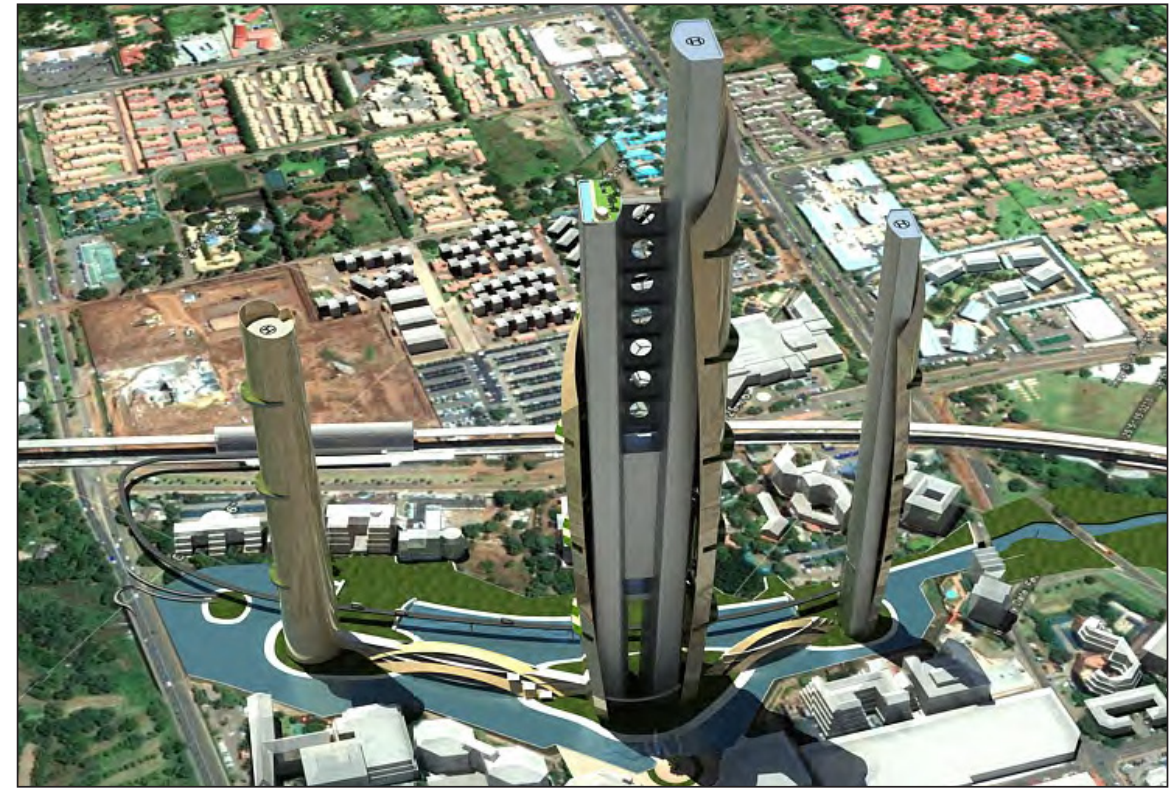

Figure 1: Proposed Symbio City Project

Source: Tshwane Economic Development Agency

lack of focus in poorer communities, not recognising the need to invest and re-make the public environment in these areas (Southworth, 2003; Schaug, 2003). This has often been linked to many local authorities who maintain that there is a limited budget for Urban Design projects, especially in poorer communities. However, given the history of urban form in the country, where during apartheid most of the infrastructure development focused on the former White areas, the exclusive use of urban design for well-developed and wealthier areas raises concerns about equity and the goals of spatial restructuring and transformation advocated in the National Development Plan (2013).

Instead, developers and local authorities have mainly focused on the incorporation of Urban Design in 'flagship projects' related to nodal development in the major metropolitan municipalities. The City of Tshwane is a good example. The City also experiences high-level Urban Design of the nodes as giving the metro a competitive edge and assisting in attracting private sector investment and residents to the metro. It focuses on doing so through the major 'flagship projects' that are planned for the metropolitan area and that are linked to prominent nodes on a metropolitan-wide level.

Centurion, in particular, is marketed and envisioned as such a major metropolitan future node with 'major attractor projects' - notably the African Gateway, Symbio City and the Tshwane International Conference Centre - with the Gautrain Station providing it with a significant competitive edge. Symbio City (Figure 1), for instance, is planned as a major 'green project', with an emphasis on sustainability and high-quality public space, which includes the redevelopment and upgrading of the Centurion Lake and major pedestrian walkways to link the Gautrain Station; proposed skyscrapers in the lake, and a rejuvenated Centurion Mall. Due to the compactness of the project, it will enable the optimal use of public transport, including a monorail system, with a situation envisioned in the node whereby it would be possible to move away completely from private motor car-based transport and to generate renewable energy from natural resources and building waste (Oranje \& Landman, 2014). These ideals and objectives of course, once again, require urban designers of the highest quality.

It also questions the role of Urban Design in terms of restructuring spatial environments. The focus only 
on flagship projects in priority nodes underplays the potential thereof to offer guidance to restructure and re-shape the city at a district or precinct level. Dewar and Uytenbogaardt (1991: 19) maintain that urban environments should promote the freedom for individuals to act. Given this, the urban structure should offer sufficient guidance to guide and release actions, without inhibiting creativity. Only in this way can stimulating, diverse and complex environments emerge over time. Establishing such a structure or public space network creates, what Crane (1960) called the capital web. The pattern of blocks and the public space network, together with the basic infrastructure and other more permanent elements of the urban area constitute the visible elements of the capital web. The capital web structures the city, its land use and values, the density of developments and the way in which people move through, and perceive the city (Carmona, Heath, Oc \& Tiesdell, 2003: 67).

However, there are a number of challenges for Urban Design in South Africa in terms of the transformation of space. These relate to the vision and the needs. First, working with a unified vision is a major challenge. There are opposing paradigms of public space related to either an African or an European version of space, which involves completely opposite conceptualisations of private and public space. The vision is also influenced by either a formalistic (focusing on aesthetics) or functionalistic (focusing on specific needs such as informal trading) approach. With these contradictions, it then becomes a major challenge to obtain the buy-in of various stakeholders. Secondly, the challenges relate to the use of public space. There are many contesting claims, where some people consider certain uses as unacceptable, resulting in a retreat from public space and various forms of privatisation. Consequently, the management and ownership of public, pseudopublic or common privatised space become an ongoing challenge. Finally, the notion of public space and public use is also questioned in a culture of non-urbanism, which still prevails among many South Africans (Landman, 2016).

Given this, there are no conclusive explanations as to why Urban Design remains weak. Is it a matter of contested significance, restricted budgets, inappropriate projects, competing visions, or opposing needs? It is thus necessary to reconsider the role of Urban Design by examining real-life experience and projects, in order to understand the low profile and limited recognition of Urban Design in the country. The article utilises case studies from different countries such as the United States of America, Argentina and South Africa to reflect on the questions introduced and their relevance to the local context. The selection criteria are related mostly to their clarity and impact and to the potential correlation and application to existing practices in South Africa. This is followed by a general discussion reflecting on potential prospects and by the conclusions.

\section{CASE STUDIES AND PRACTICE SCENARIOS TO ILLUSTRATE THE POTENTIAL OF URBAN DESIGN IN CITY-MAKING}

The following case studies embody many of the challenges and paradigms that the field presents to the urban designer, locally and internationally. The first two, from the United States of America and Argentina, respectively, highlight the importance of reflecting on, and learning from largely unplanned processes that resulted in highquality spaces and the need to assimilate and apply this concrete knowledge as promoting evidence for the profession and for future interventions. By contrast, the last case study from South Africa stresses the importance of managing the appropriate strategies for achieving a well-conceptualized, thoroughly planned urban vision if such vision is indeed attainable at all. Case studies 1 and 2 fit the category in which natural events, coupled with debatable engineering, led to unplanned, great urban results.

\subsection{Case 1: Debatable engineering, great urban design}

The first case from California can assist in providing preliminary insight as an introduction to the theme. In the wake of the 1989 Loma Prieta earthquake, the longdiscussed debate over the demise or completion of the double-decker elevated Embarcadero Freeway in San Francisco's waterfront was finally settled. Executed in the late 1950s, it was the consequential road extension of the bay bridges that were completed in the late 1930s. The project as a whole connected the Golden Gate Bridge and the Oakland-San Francisco Bay Bridge with a series of different structures, which included the elevated Embarcadero section and a central unbuilt segment (Figure 2).

Public acceptance and support were polarized from the onset, with detractors concerned about the negative urban impact imposed and supporters concerned about the economic implications on certain areas of the city if removed (Wildermuth, 2010). While major protests took place during the early 1960s, no conclusive outcome or action was taken until 1985, when the proposal for removal was officially considered and later brought to the polls in 1987. Although this proposal was defeated, it set a clear precedent about the importance of the public opinion's role in infrastructure planning. The many arguments supporting the removal ranged from visual, noise and safety concerns to more intrinsic ones related to the disregard for the essence of San Francisco as a city born out of its port infrastructure. The freeway effectively separated the waterfront from the urban fabric. The epitome of this condition was right at the heart of the city's central district area, where the imposing Ferry Building terminal is located intersecting Market Street 


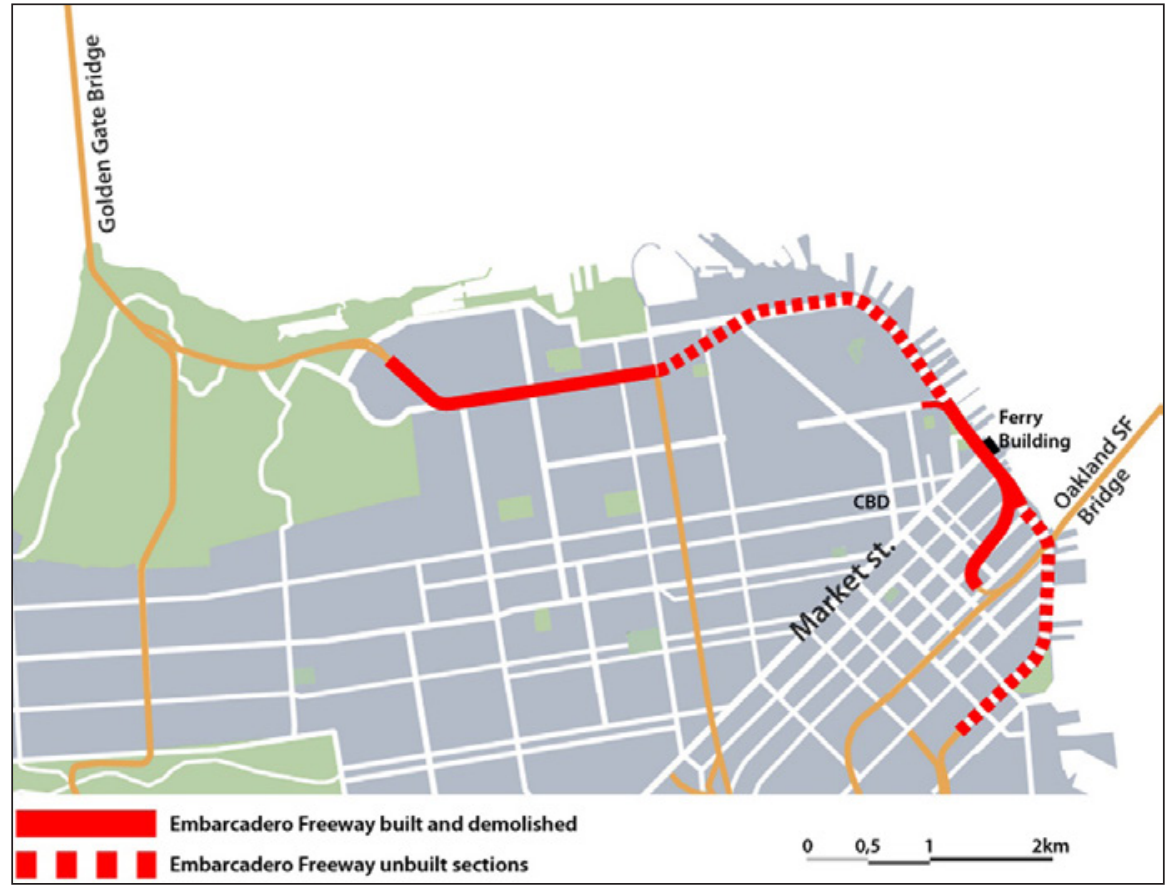

Figure 2: Central area of San Francisco and the Embarcadero Freeway trace Source: $\quad$ Authors, 2008

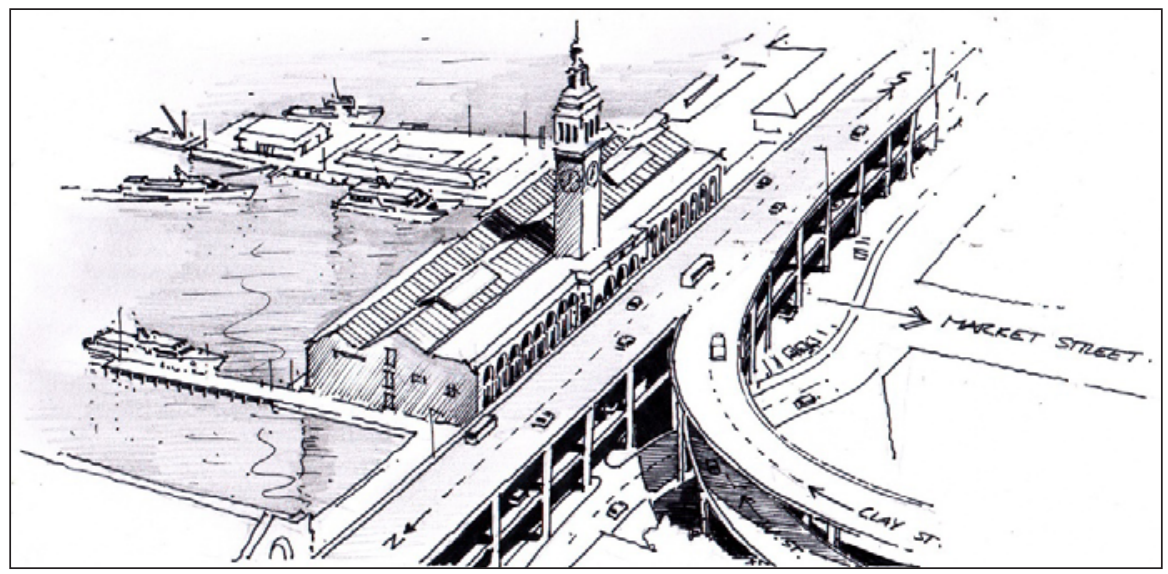

Figure 3: Diagram of the double-decker Embarcadero Freeway and the Ferry Building

Source: $\quad$ Authors, 2018

(Figure 3). This particular building was completed in 1898 and is integral to the city for its history, function, architecture, and elegant presence. With the decline in water travel after the opening of the bay bridges, the building was negatively restructured and re-functionalized in the early 1950s and finally blocked off by the Embarcadero freeway itself in 1959 (Ferry Building Marketplace, 2018: online).

After the 6.9M earthquake, the elevated structure, like several others in the area, was damaged and closed to traffic. Costly reparations and, most notably, the Ferry

Building itself (Figure 4), which was completely restored, renovated and re-programmed in 2002 by BCV Architects. The structure demise signified the re-union of the city with its waterfront and port infrastructure. Although resistance to the project was voiced from its conception, it was only after this particular event, a natural disaster, that its fate was conclusively determined. The removal of a derelict piece of engineering controversially imposed made room for great city conditions.

\subsection{Case 2: The Nueva Costanera lake promenade in Villa Carlos Paz, Argentina}

The city of Villa Carlos Paz has given its back to the body of water formed by the San Roque Dam ever since its completion in 1944. The seasonal and fluctuating level of the lake, ${ }^{1}$ combined with a gentle topography, made appropriation of its shores impractical. In 2011, a new $2 \mathrm{~km}$ long promenade, access road and lineal park were built on landfill along the eastern shores of the lake as the first step towards controversial, mixed-use private developments, with a strong emphasis on recreation. Promoted by the Provincial Government, it ignored previous proposals by the local Institute of Urban and Environmental Planning [CPUA] that remarked the public nature of these lands (Bina, 2004: 32) and the importance of preservation (Díaz-Orueta \& Lourés-Seoane, 2003). The project was officially named Corporación Puerto San Roque. These publicly owned lands had been leased to various sport and recreation clubs that enjoyed direct access to the lake's water edge, thus making unclear the status of ownership of the lands. In line with the original plan, all the stands had been reacquired by either expropriation or termination of the leasing contracts and were temporarily accessible to the public by early 2011 (Bina, 2017: personal communication).

was demolished (see Figure 2).

Today the Embarcadero Boulevard constitutes an attractive part of San Francisco with parks, restaurants, historic street cars, heritage buildings
1 Note: 'Lake' is the erroneously given name to the San Roque Dam, but officially accepted. 

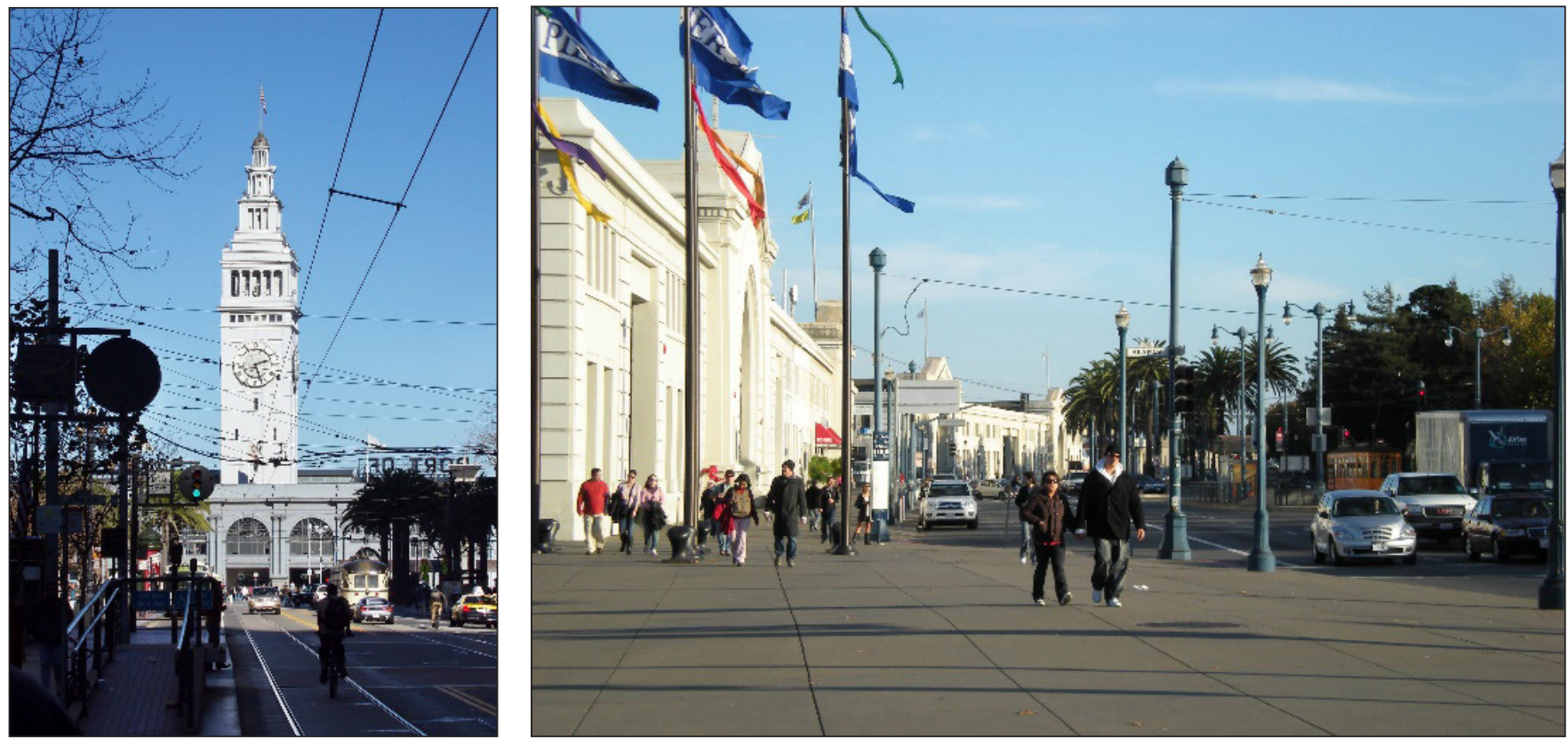

Figures 4-5: The Ferry Building as seen from Market Street and the Embarcadero Boulevard Source:

Authors, 2008

The available land constitutes an area of 19 ha, which represents mostly open space with only a few municipal buildings and sport fields constructed (Figure 7). The promenade itself was conceived as a small pedestrian boardwalk combined with a generous vehicular road and parking spaces (Figure 8). Promotion of the project resulted in the need to celebrate the first completed step with an official opening in October 2011. Initially, the promenade was only modestly used, the traffic speed was simply too high, and the pedestrian boardwalk awkwardly small (Bina, 2017: personal communication).

Only five months after its inauguration, the San Roque Dam raised significantly above spillway level and completely flooded the promenade and adjacent lands. Although unusually high, the water level was neither unexpected nor extraordinary. The result was a severe, uneven settling of the compacted subsurface which was inappropriately built, thus causing cracks and changes in surface levels. Consequently, the road was closed to traffic for its entire length. During the ensuing legal process of determining responsibilities and a potential repair solution, the public started to intensively use the damaged road for various sports such as cycling, roller-blading, running, and other similar activities. It soon became

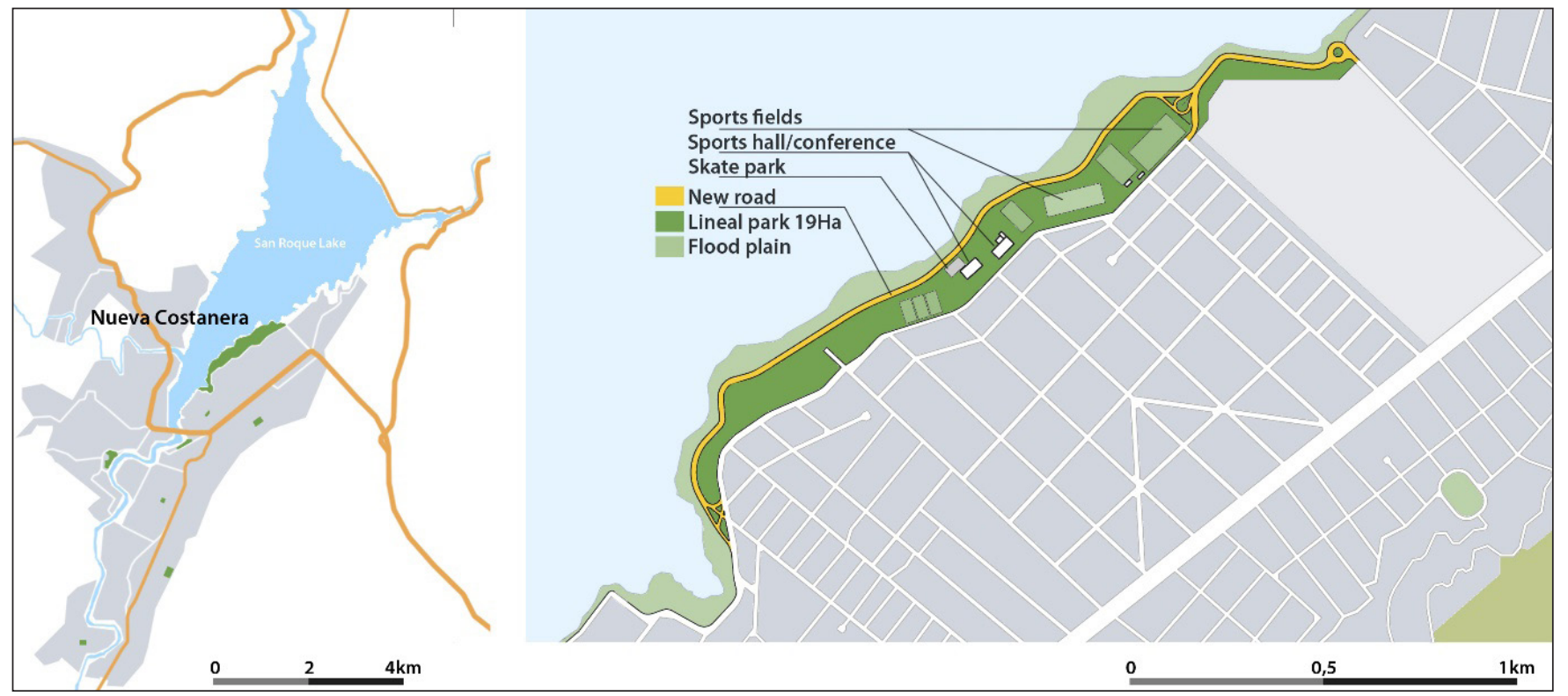

Figures 6-7: Location and plan of the Nueva Costanera, the largest (unintended) green space in the city.

Source: $\quad$ Authors, 2018 (based on Municipality of Villa Carlos Paz building codes, catastro) 
popular, particularly with small children learning to ride bicycles in a safe environment with great views and ample green areas. The small pedestrian boardwalk was used for slow walking, fishing, and seating.

In early 2012, the Municipality decided to permanently close the road to vehicular traffic, based on its usage and with the support of the public, but more crucially with the change of Municipal governance, which was ironically influenced by the CPUA original proposals. Due to its spontaneous success, the new government, led by Mayor Avilés, opportunistically did not pursue the original developing plan, but used the auspicious phenomena as a sign of its 'vision', ending at the same time the controversy over the development and ownership of those lands. The residents generally perceived the park and promenade as a gift by the new government to the city, as, although public, the area has been historically occupied by private clubs (Bina, 2017: personal communication). This strategic move proved not only popular, but also politically a major achievement; it greatly contributed to the re-election of Mayor Avilés for a second term in 2016.

Nowadays, the area is associated with sports, recreation and leisure in a safe and inclusive area.

A continuous urban transformation and upgrade slowly started to take place in the form of new restaurants, bars, hotels and other mixed-use developments adjacent to the lineal park in the existing urban fabric, as noted in Figure 10. The project is an asset that highlights the attractions that shaped Villa Carlos Paz into the second most popular tourist destination in Argentina, putting the emphasis exclusively on people. This project has been praised

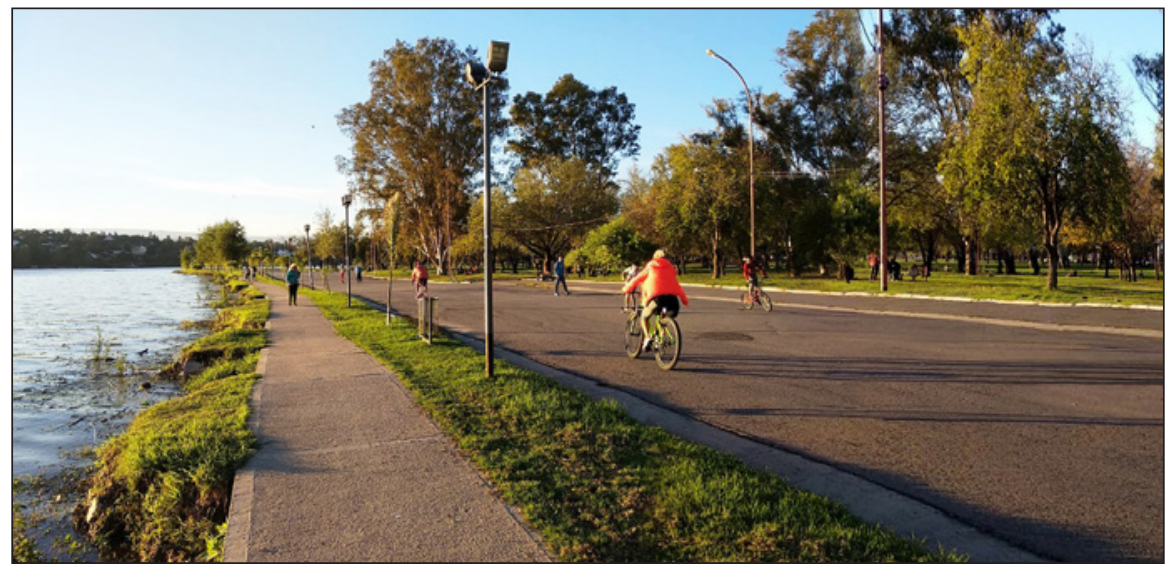

Figure 8: The promenade, note the small boardwalk, former access road and park

Source: Picture by Schoulund, 2018 (for the authors) widely by those unfamiliar with its record. It is only by the happy and unlikely succession of unplanned events that this great space has become a reality. The flexibility and scale of its configuration allow for different events to take place. It has become a classic stop/team base for competitors of the Dakar and World Rally Championship, to name one example.

\subsection{Case 3: Assertive urban vision, inevitable engineering: Balfour precinct upgrade, Johannesburg}

One particular and prominent challenge in the decision-making process of urban projects is the validation of proposals through concrete data or statistics. In this light, aspects that are quantifiable and that result in typified solutions become more difficult to scrutinize or negotiate and stand a better chance to be implemented compared to value-based Urban Design related to the specific context. Yet many multi-million projects are based, and often implemented, solely on assumptions and common sense, especially when the issues are visible and apparently straight-forward. Road infrastructure and traffic congestion are one extreme example in that it is a highly palpable issue, easily quantifiable, supported by standard solutions, and, therefore, almost non-negotiable. Large road reserves are usually perceived as land banks for future traffic upgrades and less so as an opportunity to accommodate other vital components

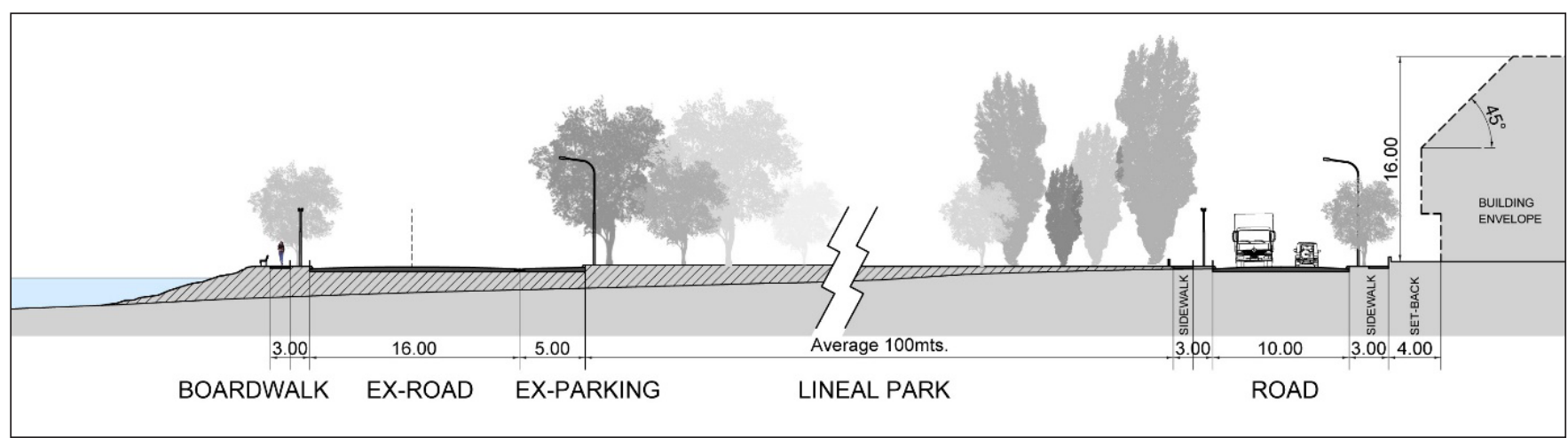

Figure 9: Diagrammatic section of the promenade and lineal park

Source: Authors, 2018 


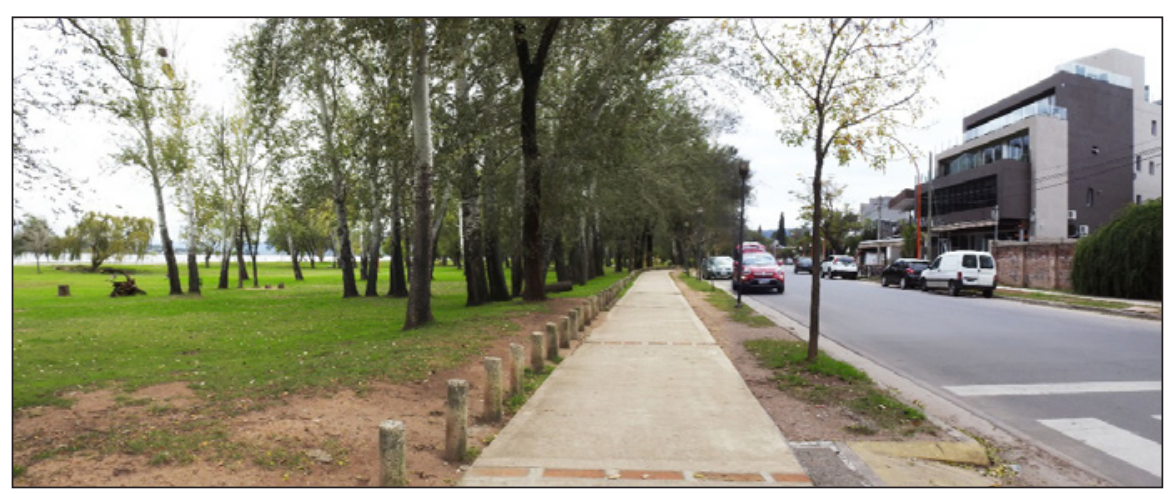

Figure 10: New mixed-use developments on the urban edge, replacing low-density housing

Source: Authors, 2018
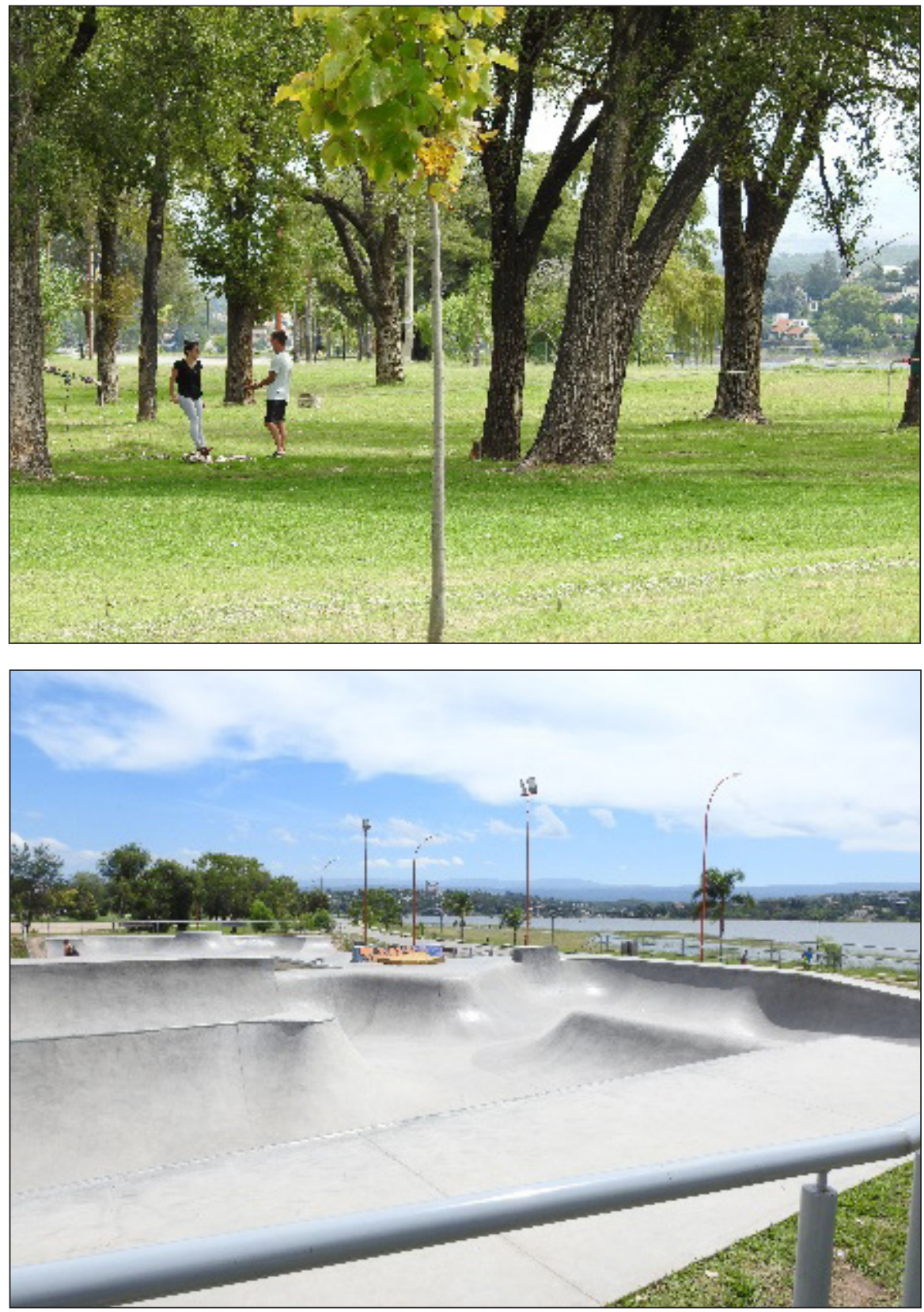

Figures 11-12: The vast and flexible lineal park and a recent addition; a skatepark built in 2017

Source: Pictures by Schoulund, 2018 (for the authors) of great streets that could, in turn, alleviate the traffic situation.

The Johannesburg Development Agency's [JDA] vision for the "Corridors of Freedom" project is a Transit Oriented Development [TOD] strategy that includes urban renewal, improved accessibility, consolidation, and upgrade of several city nodes along its Bus Rapid Transport [BRT] routes. JDA clearly summarises the project motivations and objectives as follows:

The corridors of freedom key features are:

- Safe neighbourhoods designed for cycling and walking, with sufficient facilities and attractive street conditions;

- Safe complete streets with features to calm traffic, control vehicle speeds and discourage private transport use;

- Mixed-use developments where residential areas, office parks, shops, schools and other public services are close together, stimulating economic activity and creating opportunities for emerging entrepreneurs;

- Rich and poor, Black and White living side by side - housing options provided cover a range of types, including rental accommodation and prices;

- Limited managed parking to reduce the amount of land devoted to parking and further discourage the use of private transport, and

- Convenient transit stops and stations.

In 2017, Ntsika architects and urban designers were appointed to shape JDA's urban vision for the Balfour precinct node, which sits along the Alexandra-CBD corridor on the intersection of Athol Road and Louis Botha Avenue. These nodes are considered an area of approximately 600 to 800 metres radius from its BRT station. The Balfour node, in particular, is highly accessible by road, with diverse retail options and low residential densities, except for a few specific sites. High volumes of pedestrian traffic are experienced at times during the day as a result 


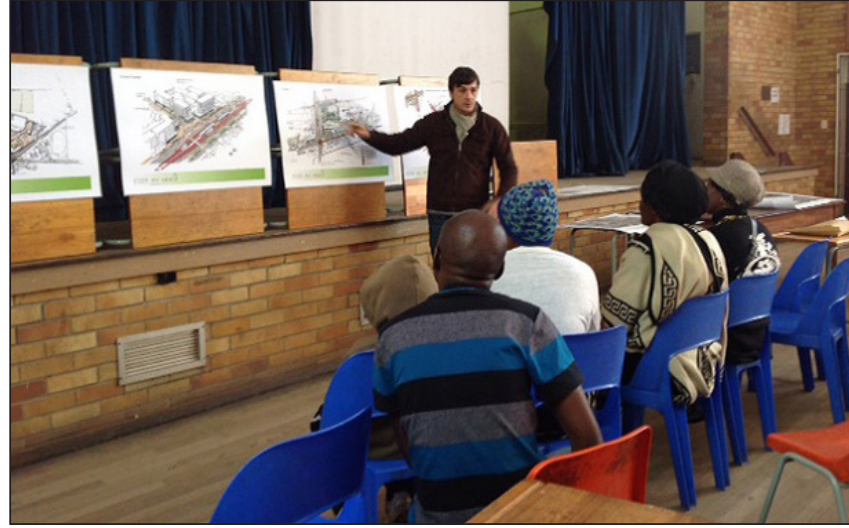

Figure 13: Preliminary design sessions Source: $\quad$ Authors, 2017

of the various schools along Athol Road. The safety of the students was, therefore, a particular consideration from the onset. The design process, managed by JDA, was multidisciplinary and participative, with a strong emphasis on stakeholder involvement. The Urban Vision would then be the outcome of the extensive background information review, the particularities of the BRT system design, the team's expertise and the understanding of the area, combined with the outcome of the public engagement process.

The community participation process, led by Letsholo Consulting, was remarkably comprehensive and the urban designers were an integral part of these workshops. During June and July 2017, the various groups concerned with the area were engaged in specific and general discussion sessions. The methodology adopted centred, in the first instance, around Participatory Mapping as the main tool for engagement (Figures14-16). This consisted of aerial photographs, on which, upon specific questions, the participants would draw relevant aspects or events in a colour-coded fashion. Usually, one person would start drawing and others would follow by contributing more information. Secondly, questionnaires were handed out at each meeting; these were related to general aspects of the area such as security, walkability, hazards, strengths, and so on. These would be used to count repeated

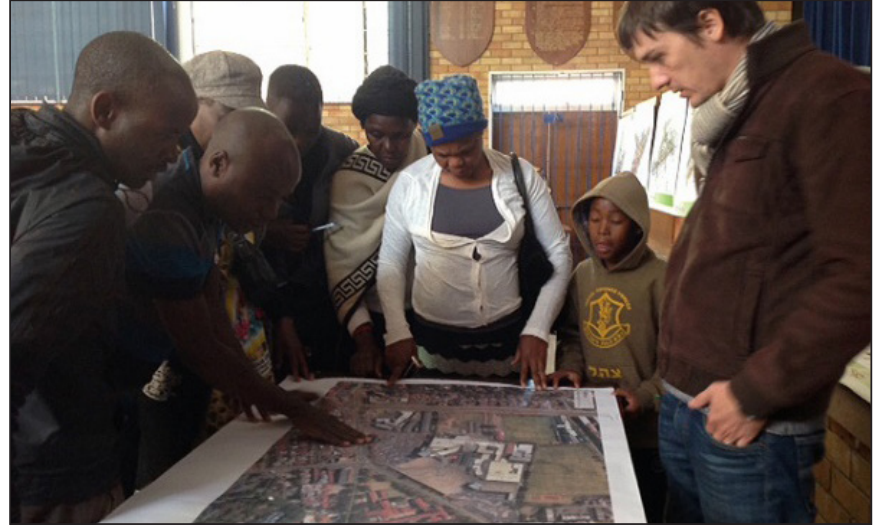

Figure 14: Participatory mapping

Source: $\quad$ Authors, 2017
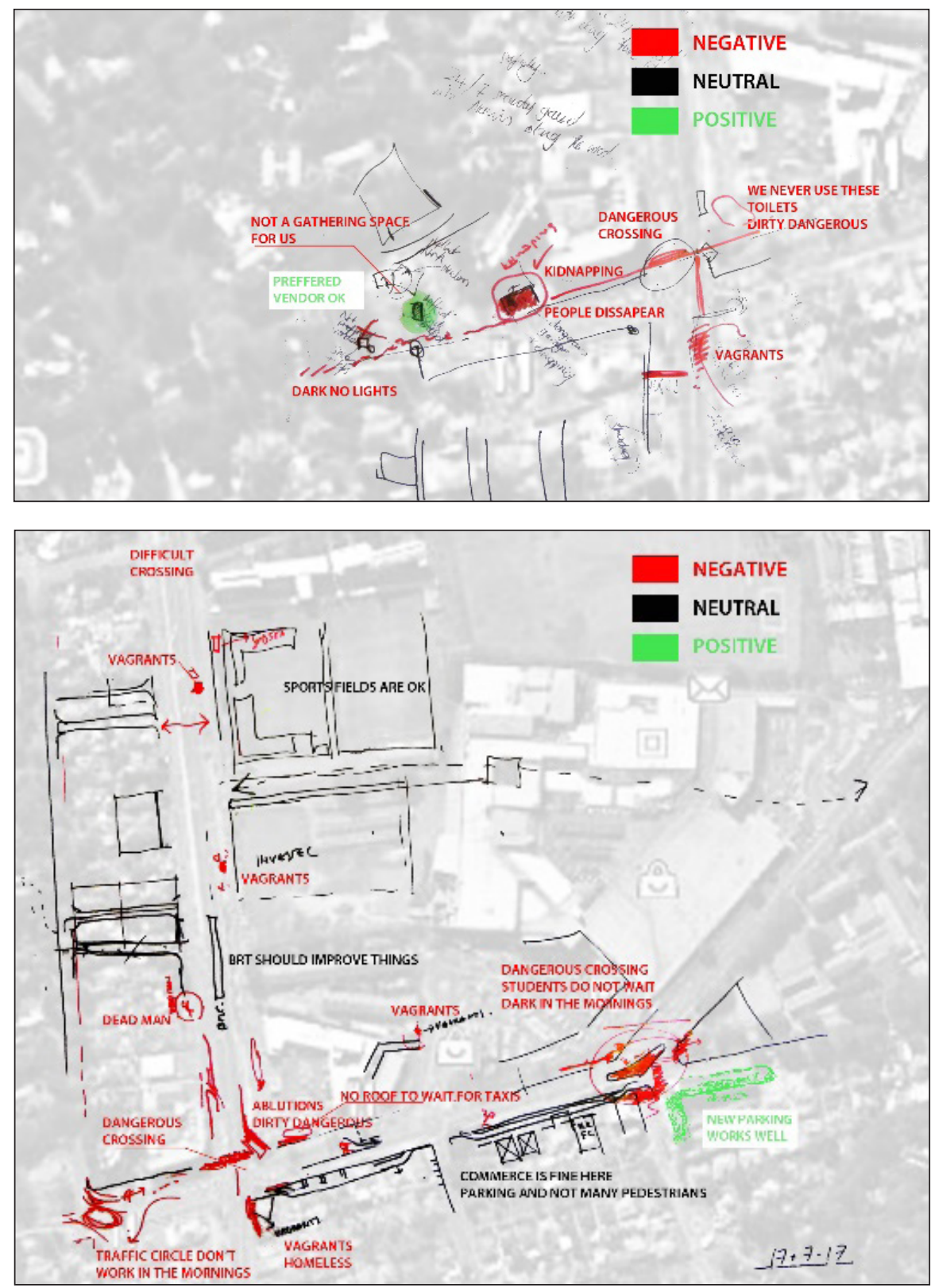

Figures 15-16: Produced maps, note how different groups focus on different areas; schoolchildren on the right are concerned about their daily route to and from transport.

Source: Authors, 2017 


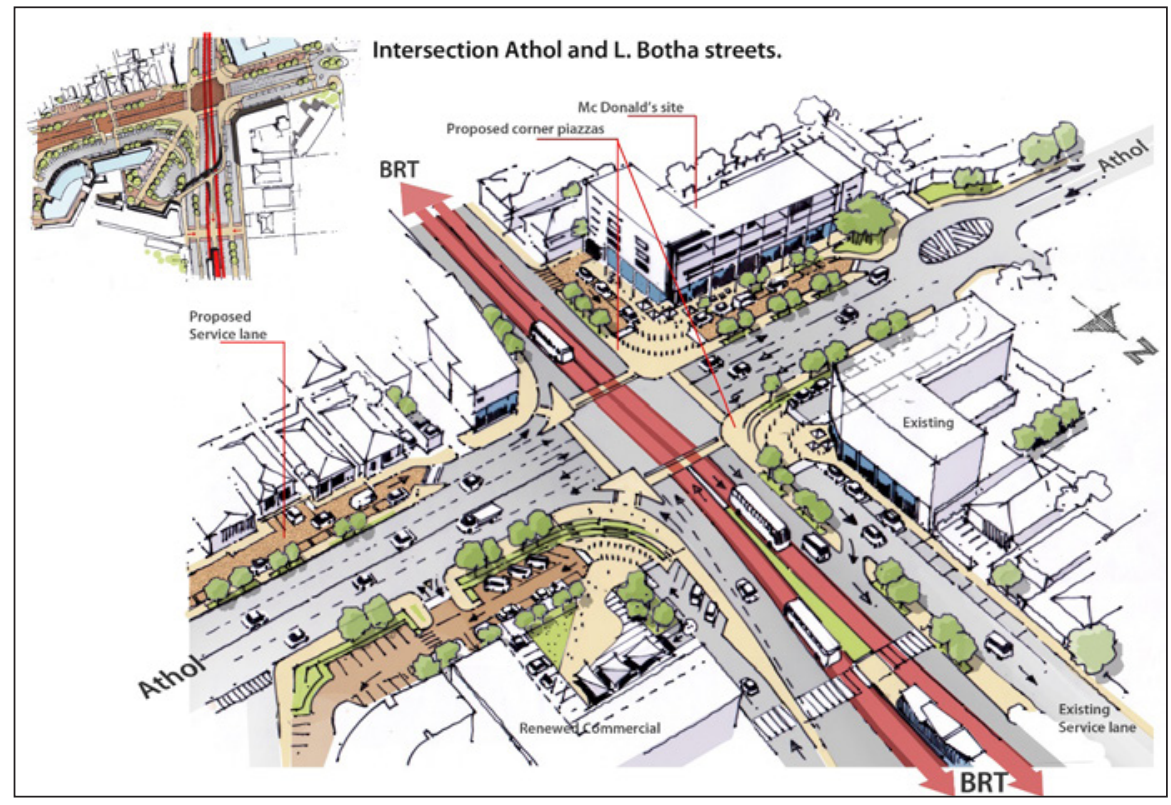

Figure 17: Conceptual Urban Design proposals for the Balfour node

\section{Source: Ntsika Architects, 2017}

keywords in order to establish and organize priorities on issues that need urgent response. Lastly, preliminary design presentations were discussed at each meeting (Figure 13). For this purpose, the urban designers prepared a series of hand-drawn perspectives depicting potential urban scenarios. The goal of this exercise was to evaluate the response to tentative proposals and to encourage creative thinking for possible solutions addressing the needs and constrains of the node, as viewed by the public.

The outcome of the community participation process was rich and revealing. Schaug (2003: 156) argues: "Meaningful consultation with real-life clients often uncovers factors which would otherwise remain unknown. These factors can frequently be of vital importance, and failure to take them into account will inevitably lead to failure of the product." The participatory mapping method produced maps of concrete issues as well as maps of events and collective knowledge, of urban tales and narratives, giving particular meaning to different areas and places (Filep, Thompson-Fawcett \& Rae, 2014). The combination of physical facts and abstract realities was rendered into the maps. The questionnaires were particularly useful in summarizing recurring preoccupations by the different groups. The preliminary design discussions were generally well understood and, in many instances, provoked the participants' 'what if' reaction, that is, alternative proposals that were triggered by the perspectives and that were mostly related to specific functional needs. The invaluable body of information and insight gained through this process was crucial for the conception and contextualization of the subsequent proposals.

The early urban designer's suggestive and high-level proposals are clear in several aspects that capture JDA's vision and the public considerations fairly (Figure 17). In general terms, there is a strong relation between the desired urban setting and the street infrastructure necessary in order to achieve that. Considering re-development in the medium-long term, these streets take into account a potential scenario with suggested building types. There is an intention of specific street types that relate to the proposed active edges and envisioned architecture with different pavement textures to indicate the various modes of transport. More importantly, the streets are treated as the main public space. A specific street type was proposed to address activity and transportation for a critical segment along Athol Road; the multi-way boulevard.

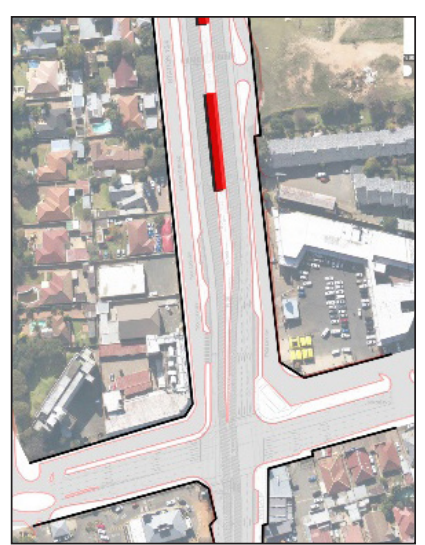

Proposed BRT layout

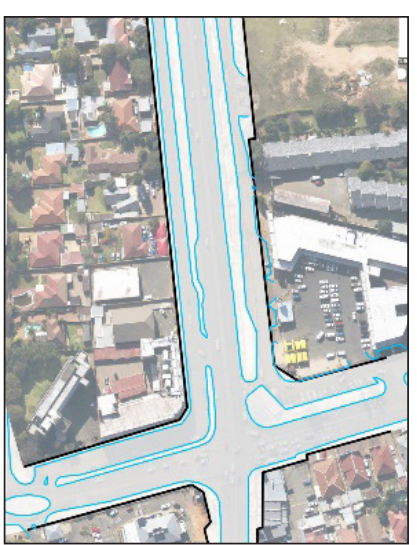

Existing layout

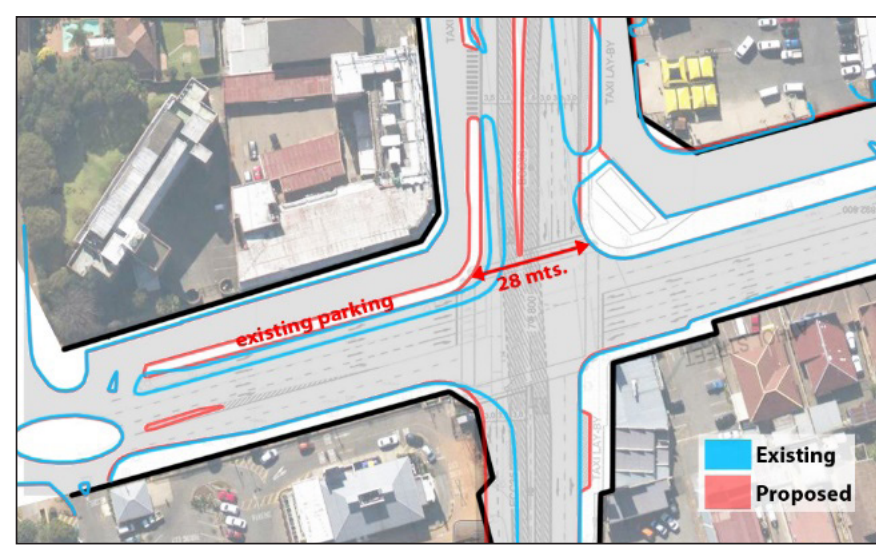

Proposed and existing layout

Figure 18: Comparisons between proposed and existing road layout. The paved area for vehicular traffic increases significantly, leaving less space for other street components

Source: Ntsika Architects, 2017 
The City of Johannesburg's Complete Street Design Guidelines manual (City of Johannesburg, JRA and Gibbs) was used for reference on appropriate street types. This is a comprehensive document that describes well in design guidelines the activity and transportation spines and suggests the corresponding built environment. But, in this instance, a particular aspect played a role which is recurring throughout Johannesburg: traffic congestion. In the opportunity that a new project represents to upgrade traffic volume and flow, road surfaces are enlarged, and new lanes added. The road proposal for the Balfour precinct reflects this approach, as Athol Road is currently a major east-west connector in apparent need of upgrading (Figure 18). The result would be the lack of space for other important components of the street and a compromised street type that does not reflect and cannot possibly accommodate the well-conceptualized JDA's vision.

\section{DISCUSSION: A PROSPECT FOR URBAN DESIGN IN SOUTH AFRICA}

Lund-Kriken (2010: 246) defines the flexible, spontaneous, human and adaptive nature of Urban Design as follows:

\section{Good city building is not created by complex statistics, functional problem solving, or any particular decision-making process. \\ Successful cities instead come from people advocating easily understood human values and principles that take into account the sensory, tactile, and sustainable qualities of environment and design in relation to what is the best of human endeavour.}

If open to, and receptive of these concepts, the Urban Design profession and its role in South Africa could re-position itself and benefit from a perspective that is perhaps more appropriate to its context. The construction of great public spaces, even if unplanned, carry a strong human component that surfaces at the critical moments when key decisions need to be taken. What is important to consider are not the particularities of each case as an isolated example under special circumstances, but the opportunity for Urban Design to learn and make use of these experiences of proven results. The fact that these cases are labelled as Urban Design projects, even when no urban designer was involved, shows a clear direction as to what is expected from the profession and one that should be embraced. In the case of the Embarcadero Freeway, the positives are countless, concrete and overwhelming. If other cities in North America have contemplated the removal of freeways, then this precedent should increasingly motivate the nature of radical projects and the need to challenge those existing that are dysfunctional or represent a public liability. This concept, to remove and re-build what does not work, is still hard to conceive, as it is associated with 'bad decisions' and 'waste of money', especially if compared against the prospects of brand-new interventions and their weight, be it political or not.

In the particular case of Villa Carlos Paz's promenade, the project in its actual configuration would have been highly improbable to conceive and implement. Yet it resulted in the most democratic and biggest green space the city now possesses by a large measure. The proposal by CPUA was a more modest version, but one that was considered appropriate for its function and one that ultimately, and crucially, influenced the decision to keep the area accessible and public. As in the first case, it was not a conscious decision, but the result of a natural event and construction limitations that played the decisive role in determining the project's fate. Building on the public's approval towards this area, the municipal government has promoted at least one other project that has been in the pipeline for many years with no definitive direction. This proposal is a continuation of the lake's promenade into the central area of the city, this time conceived in a planned and consensual manner, finally tilting the balance to a full pedestrian public space/bridge that connects both margins of the San Roque lake. The lessons learnt from the unplanned project were implemented to conceive and promote this specific, thoroughly planned project. It therefore, reinforces the notion of co-evolution and an example of how urban designers can give direction, but simultaneously leave room for spontaneous reaction to the local people and place through the coevolution of ideas and proposals for spatial interventions, as advocated by the proponents of regenerative development and design (Mang \& Haggard, 2014). It also reaffirms the way in which urban design can set a strong framework for many other professionals and citizens to react to over time. National Treasury, through its Urban Network Strategy promoted by the Neighbourhood Development Programme, involving the revitalisation of key urban hubs across South Africa, offers an example of such an approach. Furthermore, the role of urban design should be judged not only for its value as profession, but also for its use value to ordinary citizens.

Madanipour (2006) indicated that urban design has a significant role to play in terms of shaping the future through strong and coherent visions for cities to guide spatial change in the context of growing competition and thus the need for a more defined identity. Visions are used for localities to define flexibility of the type of future envisaged, while not being too rigid to miss new opportunities, referring to what Dewar and Uytenbogaardt (1991) called the balance between freedom and constraint. The last case study represents a well-conceived and carefully managed process resulting in contextual proposals that can, however, be easily challenged by overall functional problems of the city. More effective integration and analytical techniques, through diverse but systematic multidisciplinary methods and public engagement, can assist urban designers to engage with local places and obtain relevant knowledge, in order to co-produce meaningful interventions (Chapman, 2011). The JDA's vision 
for the 'Corridors of Freedom' should, in principle, be achievable. In the particular case of the Balfour precinct, the street design, a pivotal aspect that contemplates activity and mobility, is compromised by the inevitable and apparently logical need to resolve these problems. This resonates as an engineering, non-negotiable, driven solution. This raises the question as to what extent each component of the city contributes to construct the desired outcome. A tentative reflection would be that a comprehensive urban vision is as important as the steps and strategies leading to its realization. In this process of negotiation and design, every component from the various professional fields involved should ideally be analysed, adjusted and mediated in terms of the others, in order to collectively achieve such vision.

Education of Urban Design is another field that could certainly grow in South Africa. The undergraduate programmes in Architecture at the University of Pretoria and the Tshwane University of Technology recently introduced Urban Design as an introductory subject that could lead students to later consider a master's degree in the field. In addition, the postgraduate coursework Master of Planning at the University of Pretoria also includes a module, "Introduction to Urban Design”. More options at postgraduate level could help overcome the challenges of Urban Design education in the country. As a field that falls between Architecture, Landscape Architecture and Planning, it needs input from all and be able to stand on its own and develop its own identity through a merger of knowledge and the development of its own theory (Schurch, 2013). The actual demand for graduates and its projected increase positively promote the profession as an attractive option or alternative to more traditional postgraduate studies. The University of Cape Town has re-structured its master's degree programme as a one-year course instead of two, an option that could be more attractive and that follows a global trend. This reiterates the call to consider Urban Design as both a profession and a discipline, where the discipline would be promoting the knowledge and values of urban design, while the profession would be oriented more to its practical implementation in South Africa.

Ultimately, Urban Design in South Africa may better define its stand by reconsidering its role with a strong association to what it has to offer, rather than to what it is. Given this, the role of urban design as product and process should celebrate its multidimensional nature, rather than considering it as a threat. The urban designer consequently needs to be competent in other fields that participate in the citymaking process, in order to bring quality at the essential and critical stages of conception. In a context where data validation, especially of quantitative nature, represents strong driving forces, qualitative analysis, research and the study of precedents with proven results will increasingly need to be part of the urban designer's skills to promote and motivate proposals.

\section{CONCLUSIONS}

The significance of urban design lies in the role it plays in the overall transformation of cities. As political, economic and cultural changes have given a new significance to cities, urban space is being reshaped to accommodate the new urban conditions. In its broadest sense, urban design is the tool of this reshaping, hence its structural significance (Madanipour, 2006: 191)

Considering the general status of Urban Design in South Africa, its many limiting factors, challenges and potential opportunities have not conclusively answered the question as to why it remains a weak and tenuous profession with no particular or clear direction Yet, it started to highlight a number of challenges and constraints facing the profession in the country. These include: rigid visions, instead of strategic guidelines, not conducive to change and adaptation; a strong tradition of non-negotiable engineering first, recipe-based and functional problem-solving approaches; data and statistics validation as important design drivers compared to qualitative, contextual assessments where the human component, collective knowledge and needs carry a strong weight in the decision-making process; challenges related to limited options available in terms of further education, and an unclear professional territory for Urban Design, due to overlapping fields of action. Furthermore, the general association to 'flagship, luxury projects' and the general lack of focus on poorer communities is another area of concern. However, urban design interventions in the Violence through Urban Upgrading (VPUU) Project in Khayalitsha is starting to highlight the value of the profession to contribute to safer and more enabling environments in poorer communities.

The discussion, however, also indicated that it would not be useful to only focus on building the profession, in order to strengthen the role of urban design in South Africa. In addition, there is a need to build the discipline of urban design, raising awareness of its potential, and building the knowledge to convince both decision-makers and users of its value for South African cities. Thus, focusing on the discipline could make provision for the profession to lead the way in shaping the urban form and incrementally restructuring the parts of South African cities through the establishment of a strong coherent vision together with a network of public spaces or a capital web to enable other actors to respond over time.

In understanding real-life experiences and projects that were defined from different, sometimes unintended perspectives, in which human values and public opinion played an important role, a possibility presents itself to re-consider the role and value of Urban Design in South Africa, in order to strengthen its presence and recognition. Based on the learning from the article, it is important to include the human component and 
its local uniqueness or spirit of the place in the planning process. This can be achieved with more focus on studying public life, where qualitative aspects could be quantified as supporting, promoting evidence in line with the dynamics of actual planning practices. Authors such as Ghel \& Svarre (2013) or Bosselmann (2018) have greatly contributed to defining useful methods for such undertakings. Secondly, urban design processes should allow for spontaneous responses reacting to local place and people, building strong frameworks, and working with multiple methods and processes to enable this. Thirdly, it is important that all professionals involved in city-making should engage with communities by listening and discussing possibilities. In this process, urban designers can create facilities and opportunities, due to its integration of the discipline's role in rethinking alternative approaches to standard solutions and ways of gathering data. Thus, the community participation process should be managed, but not exclusively undertaken by external consultants, as it can rapidly become a bureaucratic formality with no real value attached. Fourthly, it is imperative to promote streets as public spaces (for all) and not only as transportation routes (for few). In this light, the urban designer needs to become competent in street and road design and with the related built environments they can facilitate. Fifthly, the association to luxury projects can only be counteracted by emphasising the service urban design brings to all communities and settings across the city. This could be achieved primarily through policymaking and fair budget allocations, but also by highlighting that it is in the poorer urban settings that the impact of urban design has comparatively the biggest and more positive effect. Finally, urban designers should learn from cases where human values prevailed, including from spontaneous and often unintended projects that show a clear direction for the public and for the profession. In this way, urban design has the potential to grow and play a more prominent role in the country and in the process towards incidental and great public spaces.

\section{REFERENCES}

AGNOS, A. 2010. Reflections on the Loma Prieta earthquake, 20 years later. Huffington Post. [online]. Available at: <https://www.huffingtonpost. com/art-agnos/reflections-onthe-loma-p_b_324350.html> [Accessed: 3 February 2018].

BINA, L. 2004. Reassessments for urban development or economic enclaves for social exclusion? Revista Trazos, 19, p. 32.

BINA, L. 2017. Director of The Institute of Urban and Environmental Planning (CPUA). Personal communication during an official meeting held at the CPUA, Villa Carlos Paz, Argentina, 3 April 2017

BOSSELMANN, P. 2018. Adaptations of the metropolitan landscape in Delta Regions. New York: Routledge. https:// doi.org/10.4324/9781315147871

CARMONA, M., HEATH, T., OC, T. \& TIESDELL, S. 2003. Public places, urban spaces: The dimensions of urban design. London: Architectural Press.

CHAPMAN, D. 2011. Engaging places: Localising urban design and development planning. Journal of Urban Design, 16(4), pp. 511-530. https://doi.org/10.1080/13574809 .2011 .585840

CRANE, D. 1960. The city symbolic. Journal of the American Institute of Planners, 26(4), pp. 280-292. https:// doi.org/10.1080/01944366008978427

DEWAR, D. \& UYTENBOGAARDT, R. 1991. South African cities: A manifesto for change. Cape Town: UPRU.

DÍAZ-ORUETA, F. \& LOURÉSSEOANE, M.L. 2003. La ciudad Postfordista: Economía cultural y recualificación urbana. Revista de Economía Crítica, 2, pp. 105-121.

FERRY BUILDING MARKETPLACE. 2018. The Ferry Building Story. Ferry Building Marketplace. [online]. Available at: <https://www. ferrybuildingmarketplace.com/about/> [Accessed: 3 February 2018].

FILEP, C.V., THOMPSON-FAWCETT, M. \& RAE, M. 2014. Built narratives. Journal of Urban Design, 19(3), pp. 298-316. https://doi.org/10.1080/13 574809.2014 .890043
GHEL, J. \& SVARRE, B. 2013. How to study public life. Washington, DC: Island Press. https://doi. org/10.5822/978-1-61091-525-0

JDA (JOHANNESBURG DEVELOPMENT AGENCY). The Corridors of Freedom Key Features. [online]. Available at: <http://www.jda.org.za/index.php/ whatwedo/programmes?id=1429> [Accessed: 14 February 2018].

LANDMAN, K. 2016. The transformation of public space in South Africa and the role of urban design. Urban Design International, 21(1), pp. 78-92. https://doi.org/10.1057/udi.2015.24

LUND-KRIKEN, J. 2010. City building: Nine planning principles for the twentyfirst century. New York, NY: Princeton Architectural Press.

LOEW, S. (Ed.). 2011. Urban design in practice: An international review. Urban Design Group, London: RIBA Publishing.

LOUKAITOU-SIDERIS, A. 2012. Addressing the challenges of urban landscapes: Normative goals for urban design. Journal of Urban Design, 17(4), pp. 467-484. https://doi.org/10.1080/13 574809.2012.706601

MADANIPOUR, A. 2006.

Roles and challenges of urban design. Journal of Urban Design, 11(2), pp. 173-193. https://doi. org/10.1080/13574800600644035

MANG, P. \& HAGGARD, B. 2014.

Regenerative development and design. New York, NY: Wiley \& Sons.

NDP (NATIONAL DEVELOPMENT PLAN). 2013. Vision for 2030 developed by the National Commission of South Africa. [online]. Available at: <http://www.npconline.co.za/ medialib/downloads/ home/NPC\%20 National\%20Development $\% 20$ Plan $\% 20$ Vision\%202030\%20-lo-res.pdf> [Accessed: 10 February 2018].

NTSIKA ARCHITECTS AND URBAN DESIGNERS. 2017. Balfour Park Precinct Upgrade - Urban Design Conceptual Proposals Report August 2017. For Johannesburg Development Agency (JDA).

ORANJE, M. \& LANDMAN, K. 2014. Nodal development in Tshwane. A research paper developed for the City of Tshwane. 
SCHAUG, E. 2003. Urban design in

Black South African settlements. Urban

Design International, 8(3), pp. 147-159.

https://doi.org/10.1057/palgrave.

udi.9000101

SCHURCH, T.W. 2013. Reconsidering urban design: Thoughts about its definition and status as a field or profession. Journal of Urban Design, 4(1), pp. 5-28. https://doi. org/10.1080/13574809908724436

SOUTHWORTH, B. 2003. Urban design in action: The City of Cape Town's Dignified Places Programme - Implementation of new public spaces towards integration and urban regeneration in South Africa. Urban Design International, 8(3), pp. 119-133. https://doi.org/10.1057/palgrave. udi.9000097

VAN NIEKERKEN, B. 2017. An ode to the embarcadero Freeway, the blight by the bay. San Francisco Chronicle. [online]. Available at: $<$ https://www.sfchronicle.com/thetake/ article/An-ode-to-the-EmbarcaderoFreeway-the-blight-by-11543621.php> [Accessed: 10 February 2018].

WILDERMUTH, J. 2010. Chinatown's champion. San Francisco Chronicle. [online]. Available at: <https://www. sfgate.com/politics/article/Chinatowns-champion-3173928.php> [Accessed: 10 February 2018]. 